Article

\title{
Corporate Social Responsibility and Sustainability. A Bibliometric Analysis of Their Interrelations
}

\author{
Víctor Meseguer-Sánchez ${ }^{1}$, Francisco Jesús Gálvez-Sánchez ${ }^{2}$ (D) Gabriel López-Martínez ${ }^{3, *}$ (i) \\ and Valentín Molina-Moreno ${ }^{4}$ (i) \\ 1 International Chair of Social Responsibility, Catholic University of Murcia, 30107 Murcia, Spain; \\ jvmeseguer@ucam.edu \\ 2 Department of Economic and Financial Studies, Miguel Hernández University of Elche, 03202 Alicante, Spain; \\ francisco.galvez@goumh.umh.es \\ 3 Department of Contemporary Humanities, University of Alicante, 03690 Alicante, Spain \\ 4 Department of Management-1, University of Granada, 18071 Granada, Spain; vmolina2@ugr.es \\ * Correspondence: gabriel.lopez@ua.es; Tel.: +34-(96)-590-3431
}

check for updates

Citation: Meseguer-Sánchez, V.; Gálvez-Sánchez, FJ.; López-Martínez, G.; Molina-Moreno, V. Corporate Social Responsibility and Sustainability. A Bibliometric Analysis of Their Interrelations. Sustainability 2021, 13, 1636. https://doi.org/10.3390/ su13041636

Academic Editor: Andrea Pérez

Received: 9 January 2021

Accepted: 1 February 2021

Published: 3 February 2021

Publisher's Note: MDPI stays neutral with regard to jurisdictional claims in published maps and institutional affiliations.

Copyright: (c) 2021 by the authors. Licensee MDPI, Basel, Switzerland. This article is an open access article distributed under the terms and conditions of the Creative Commons Attribution (CC BY) license (https:// creativecommons.org/licenses/by/ $4.0 /)$.

\begin{abstract}
Traditional economic system has brought important negative implications regarding environmental development, as well as an unequal distribution of wealth, which has led to ecological disasters and population imbalances. Considering the existence of unequal opportunities and access to resources in a global economy, it would be relevant to study the interrelations between the concepts of Sustainability and Corporate Social Responsibility (CSR). Global and multifactorial issues require the review of fieldworks and their connections. From this perspective, the present research aims to analyze the relationships between the concepts of Corporate Social Responsibility and Sustainability in order to understand the advances of current scientific production and future lines of research. In this way, there is a considerable increase of interest in this line of research, highlighting GarcíaSánchez as the most productive author, Business, Management and Accounting as the most studied topic, and Sustainability Switzerland as the most productive journal. The country with the most publications and citations is the United States, and the most productive institution is Universidad de Salamanca. Future lines of research should focus on the social dimension and its possibilities in the field of Circular Economy. Finally, a line of research is proposed that also includes the proposals from the 2030 Agenda for Sustainable Development and its 17 Sustainable Development Goals.
\end{abstract}

Keywords: sustainability; Corporate Social Responsibility (CSR); Social Sustainability; Economic Sustainability; Environmental Sustainability; bibliometric

\section{Introduction}

The concepts of Sustainability and sustainable development have acquired greater importance over time, as society as a whole has become more aware of its impact on the environmental scenario. Globalization, climate change, effective and efficient management of available resources, as well as their depletion, or the aging of the population, among others, invite society to change the direction of quantitative economic growth towards a more qualitative and responsible dimension.

The World Commission on Environment and Development (WCED) describes the concept of sustainable development as a response to 'the needs of the present without compromising the ability of future generations to meet their needs' [1]. Moreover, the United Nations (UN) has demonstrated its commitment to Sustainability through Agenda 21 [2], the Millennium Development Goals (UN, 2000) [3], and more recently, the Sustainable Development Goals (UN, 2015) [4], which offers a catalog of goals and instruments that define the human rights-based approach to Corporate Social Responsibility (CSR). These advances have brought Sustainability into the mission of numerous organizations and 
institutions, both local and international [5], and also their importance and assimilation in the social sphere [6].

In a business context, Savitz and Weber (2006) suggest that "a sustainable company is one that generates benefits for its shareholders while protecting the environment and improving the lives of those with whom it interacts". On this matter, the interrelationships among society, economic development, and environmental protection are an integral part of the concept of Sustainability $[7,8]$.

On the other hand, one of the most accepted views in this field defines CSR as "a concept through which companies integrate social and environmental concerns in their commercial operations and in their interaction with their stakeholders on a voluntary basis" [9]. From this perspective, Corporate Social Responsibility (CSR) emerges where law ends, and not only represents an aspiration of a good image or profit optimization but also a transparent style of resource management that guarantees results (economic, political, social, environmental, among others) expected, following the economic principle of mutual benefit, the legal principle of respect for the rights of others (individual and collective), and the ethical principle of preservation of non-renewable natural resources, the heritage of future generations [10]. This is not counterproductive with the coherence of the actions carried out with the aim of obtaining business benefit [11]. In this way, the main principle in the field of CSR aims to conduct moral businesses that add value to society beyond legislative guidelines [12-14]. Finally, it may be considered how the concept of CSR may differ among countries and how and why it changes over time [15].

From this perspective, the purpose of this research is to analyze the evolution of scientific knowledge based on the existing relationship between Corporate Social Responsibility (CSR) and Sustainability. For this aim, the objective is to trace the links between this binomial in order to study the main advances in this field of research, the knowledge gaps, as well as the trends, and, ultimately, the future lines of research that will focus the attention of the research context in the coming years. Our hypothesis understands the importance of analyzing sustainable economic growth, considering environmental aspects and social development, and how CSR and Sustainability cover those aspects. So, from this view, it may be relevant to review the main literature dealing with both concepts and trying to answer some questions: how do CSR and Sustainability appear in the relevant scientific literature? Who are the main researchers/experts working from this perspective? Which are the main institutions dealing with CSR and Sustainability studies? Which lines of interest could be approached in the future?

Thus, in the next section, we present a review of the most relevant literature in the field. We understand that it would be clarifying to approach the main studies from three perspectives: social, environmental, and economic-financial dimensions of CSR and Sustainability. This review is key in order to settle the field before we address our bibliometric analysis. Then, we present the methodology for this particular study and explain the scope and the intended purpose of this work. In Results and Discussion, we develop interrelations we found through the bibliometric analysis displayed. Finally, we offer conclusions that synthetize our results, and we also propose some lines for the future, which may be relevant to develop in the correspondence between CSR and Sustainability.

\section{Literature Review}

From the review of the most relevant literature in the field, we understand that it would be appropriate to establish three sections: (1) studies that focus on the social dimension of CSR and Sustainability; (2) the environmental dimension of CSR and Sustainability; (3) the economic-financial approach to CSR and Sustainability.

\subsection{Social Dimension of CSR and Sustainability}

The social dimension is commonly recognized as the weakest pillar of Sustainability (Vallance et al., 2011; Lehtonen, 2004), which means that we may find no clarity in the scientific community about its definition, criteria, and/or measurement tools [16]. This 
perspective implies that Sustainability is often considered as a "secondary importance" issue concerning the social dimension $[7,17,18]$.

However, Landorf (2011) finds that basic needs and equity are fundamental issues in Social Sustainability [19]. As for McKenzie (2004), he defines Social Sustainability as "a positive condition within communities, and a process within communities that can achieve that condition" [20]. Labuschagne et al. (2005) consider that the social dimension refers to the impact of the organization on the social systems and stakeholders in which it operates [21], while Bramley et al. (2009) propose that it should be considered as the binomial between social equity and community Sustainability [22].

Attending to this social dimension, many authors from the international community have studied the integration of social aspects into CSR and Sustainability. In this way, Dreyer et al. (2006) incorporate the impacts of products and services on health, human dignity, and the satisfaction of basic needs [23]. Norris (2006) proposes a methodology to analyze the benefits and damages to human health in the per capita gross national product (GNP) [24], while Hunkeler (2006) and Schmidt et al. (2004) integrate social considerations in environmental analysis, the first through inventory data, and the second through a "socio-eco-efficiency" analysis $[25,26]$.

Increased pressure from stakeholders has led companies to consider social problems more intensely $[27,28]$. Currently, the social dimension addresses issues, such as internal human resources, job stability, work practices, health and safety, and development of abilities and capacities [29], implying the interest of organizations in human rights, labor equity, gender equality, health and safety practices for preventive measures, or capacity development. For its part, we may also find research attending to the external population through human capital, productive capital, and community capital [30-32].

\subsection{Environmental Dimension of CSR and Sustainability}

Researchers have highlighted the role of CSR in the assimilation of environmental aspects in corporate strategies for survival and the constantly changing business environment $[33,34]$. Organizations already have social and environmental certifications that attract more buyers/clients, as a consequence of social positive perception in those organizations that develop CSR policies [35]. Wang et al. (2016) consider that CSR can contribute to the reduction of environmental impacts [36], while Abbas (2020), Shahzad et al. (2019), and Suganthi (2019) have contributed to identifying the impact of CSR policies aimed at the development of Environmental Sustainability [33,37,38]. We find some contributions pointing out the concept of a wide environmental perspective, including, for instance, the role of animals, pets, and human responsibility towards them [39].

Consequently, different studies have identified the role of innovation with respect to CSR and organizational performance [40-43], which is giving rise to the origin of new paradigms that generate a positive impact on binomial profitability and Environmental Sustainability. One of these new paradigms is the green innovation, which understands that innovative proposals can reduce the impact of its operations on the natural environment $[44,45]$. In this aspect, researchers have found that market demand leads to green innovation [46], which is reinforced through business ethics (Chang, 2011), as well as by pressure from stakeholders, both internal and external [47].

Another of these paradigms is the concept of Circular Economy. Despite being widely discussed in some studies [48-50], this perspective allows identifying the opportunities of a new industrial revolution and sustainable practices [51,52]. This can be defined as an industrial economy that is regenerative and restorative by intention and design (Ellen Macarthur Foundation, 2013). It is designed to depend on renewable energy while eliminating or mitigating the use of chemicals and waste [53].

Other current paradigms are ecotourism or improvement in supply chain management, both aimed at reducing the organizational impact on the environment [54-56]. Thus, research has progressively advanced in recent years, so it is expected that the production 
system will implement these innovations to improve the results of the traditional economic model [57].

\subsection{Economic-Financial Dimension of CSR and Sustainability}

For more than 30 years, previous literature has analyzed the links between CSR and financial performance [58-61]. It is evident that if companies find a positive relationship in this binomial, they will be more motivated to implement CSR policies aimed at an environmental and social improvement [62].

However, empirical studies on the influence on the economic results of the implementation of CSR and Sustainability policies are not conclusive. Some studies have found a positive relationship between CSR and the financial performance of the company [63-66], while Mahoney and Robers (2007) and Parast and Adams (2012) have found no significant differences between both dimensions $[67,68]$. Saeidi et al. (2014), Benavides-Velasco et al. (2014), and Pätäri et al. (2014) have identified that there is an influence, at least indirect, by improving business dimensions, such as reputation and brand image, customer satisfaction, improvement of resources and capabilities, improvement of managerial competence, acquisition of talent, and creation of goodwill [69-71].

What seems clear is that there are two clearly differentiated currents for the measurement of CSR: the one that considers it as a multi-dimensional instrument, which takes into account objectives and responsibilities in the social, environmental, ethical, and, of course, economic fields, between others [72-75], as well as that which considers CSR as an instrument to manage the expectations of interested parties, such as workers, the environment or social entities, among others [76-80].

\section{Data and Methodology}

For the implementation of this research work, the bibliometric analysis technique has been used. The main objective of this methodology consists of identifying, organizing, and analyzing the main components within a specific research field [81,82].

Through the use of mathematical, statistical, and mapping tools, a total of 3079 articles on the concepts of Sustainability and Corporate Social Responsibility (CSR) have been analyzed in order to identify the existing correlations. The main databases closely linked to the area of knowledge have been consulted [49,83], while the research works from Scopus have been selected, as they have a high number of papers, authors, and journals while meeting the peer-review requirement for scientific quality. In addition, this repository is the one with the largest volume of information provided in terms of authors, institutions, and countries [84].

The search for these research works was carried out in January 2021, while the statistical analysis has focused on the last 20 years, that is, the period of time between 2001 and 2020, since it is in 2001 when the Green Book (CEC, 2001) [85] was published, setting out the lines of European government policy on CSR, and laying the foundations for the line of research that is being analyzed.

In this sense, Figure 1 shows the logical sequence applied to obtain the data to be studied.

In this way, the year of publication, the journal, the subject area, the author and co-authors, the institution, the country, and the keywords that are included in this research have been analyzed through the VOSviewer tool [86-89]. This software generates network maps for each of the variables used, allowing grouping and processing of words. VOSviewer also allows us to construct and visualize co-occurrence networks of important terms extracted from scientific literature [90].

Finally, the evolution of scientific production is analyzed based on the number of articles published for each of the four decades that make up the last 20 years, that is, the productivity of authors, countries, and institutions, through the count of papers presented in each area, as well as the count of the number of citations, the H-index, and the SJR impact factor of the main papers. 


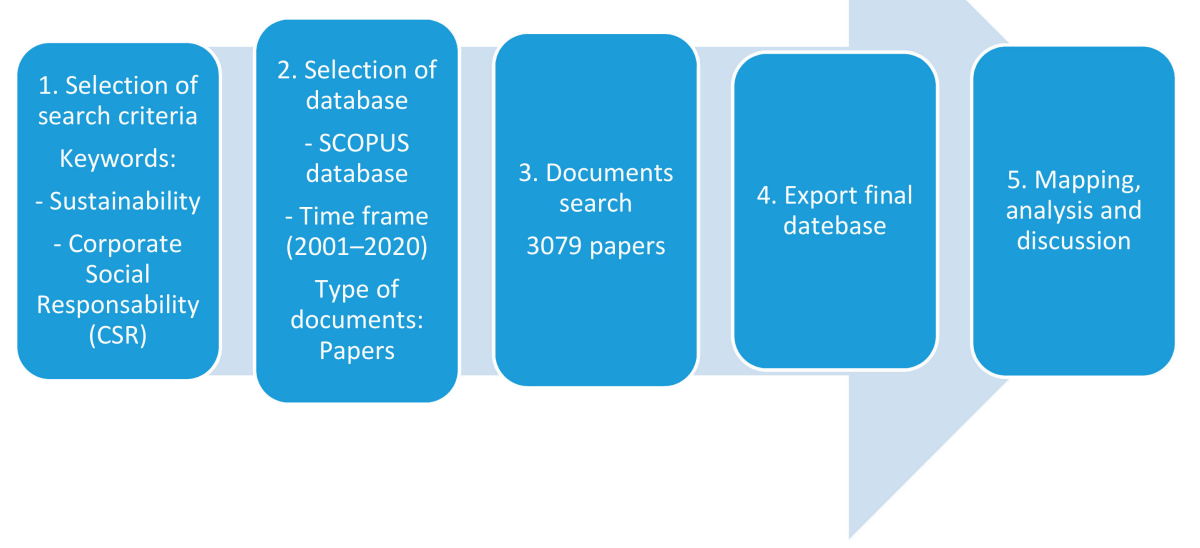

Figure 1. Flow diagram of the methodology used.

\section{Results and Discussion}

\subsection{Evolution of Scientific Production}

This section shows the main characteristics of scientific production, the evaluation of the publication of the number of articles, the percentages of variation between periods, and, finally, the total number of journals where articles are published with the research topic under study.

Thus, Table 1 shows the evolution of the main characteristics of the articles published on Sustainability and Corporate Social Responsibility (CSR) in the period between 2001 and 2020. The time horizon covers 20 years and has been divided into periods of 5 years to facilitate the analysis. In this period of time, the scientific production for the keywords analyzed has increased exponentially since the scientific production of each five-year period practically triples that of the previous five-year period.

Table 1. Characteristics of scientific production from 2001 to 2020.

\begin{tabular}{ccccccc}
\hline Year & Articles & Authors & Countries & Citations & TC/A & Journals \\
\hline $2001-2005$ & 49 & 98 & 22 & 70 & 1.43 & 37 \\
$2006-2010$ & 303 & 549 & 54 & 1316 & 4.34 & 179 \\
$2011-2015$ & 860 & 1793 & 78 & 8642 & 10.05 & 442 \\
$2016-2020$ & 1867 & 4448 & 104 & 33,490 & 17.94 & 654 \\
\hline
\end{tabular}

Source: own elaboration. (TC/A): an average of citations per article.

In this way, if in the first five years analyzed (2001-2005), only 49 articles are published, in the last five years (2016-2020), the number of publications is 1867, which represents an increase of $3810.20 \%$. The number of publications in the last five years is especially significant since it represents $60.64 \%$ of the publications in the area of knowledge analyzed.

Despite the fact that this line of research emerged in 1995 with the publication of Designing an integrated cropping systems research program: Central Agricultural Research Institute (CARI), Liberia (Francis, et al., 1995) and Agricultural extension: The question of sustainable development in Iran (Karami, 1995), it is not until 2001 when the scientific field regains interest, which could be related to the influence of the publication by the European Commission of the Green Paper (CEC, 2001) [85] on the boom of this line of research. Similarly, a rebound in scientific publications is observed in the five-year period 2011-2015, which coincides with the publication of ISO 26000, published in 2012, an international standard that voluntarily establishes a guide for all types of organizations in any productive sector to operate in a socially responsible manner in an increasingly demanding society. This significant increase is clearly seen in Figure 2. 


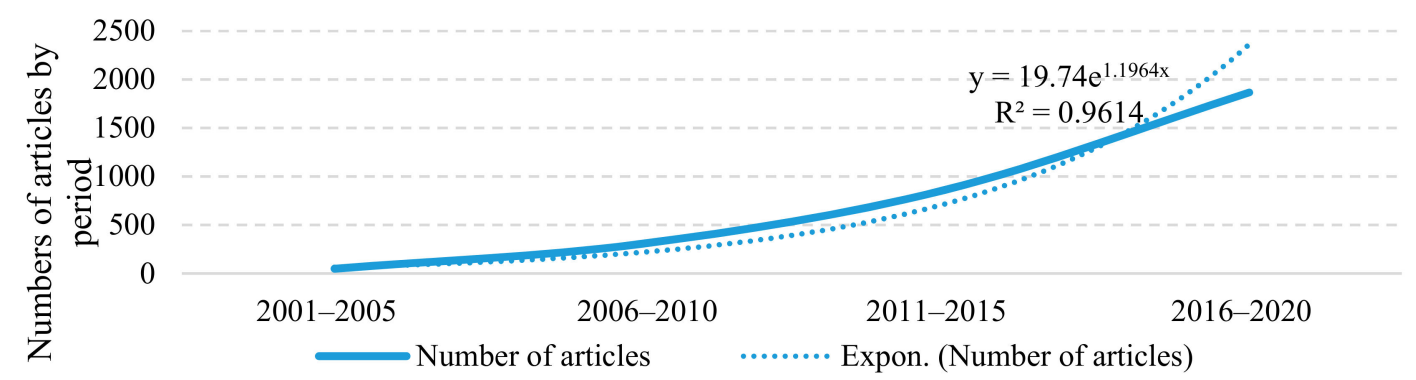

Figure 2. Evolution of the number of articles and exponential variation between periods. Source: own elaboration.

The number of authors who contributed to the research topic is 6888. Similarly, the number of articles has increased; the total number of authors has also increased gradually (64.57\% of the total authors) in the five years analyzed, 2016-2020. However, the average number of authors per article has practically remained constant over time, going from an average of two authors during the first five years to an average of 2.4 in the last.

For its part, the number of countries that have paid attention to the issue analyzed has been 258. As with the previous indicators, there has also been rapid growth, going from 22 during the period 2001-2005 to a total of 104 in the period 2016-2020, which implies that it has practically multiplied by five in just 20 years.

The number of citations has also risen exponentially, going from 70 during the fiveyear period 2001-2005 to 33,490 citations in the period 2016-2020, generating a total of 43,513 citations for the entire period analyzed. This represents an increase in the average number of citations per article from 1.43 to 17.94, which shows a significant increase in interest in the line of research.

Finally, the number of journals has grown exponentially, going from 37 in the first five years analyzed to 654 in the 2016-2020 period, representing an increase of $1667.56 \%$. In this way, all the indicators analyzed show a strong increase in international interest and scientific production, making it clear that it is a growing line of research at the beginning of the 21st century.

\subsection{Analysis of Scientific Production by Areas: Journals, Authors, and Countries}

4.2.1. Distribution of Publications by Subject Area and Journal

During the period of time analyzed (2001-2020), there have been 24 categories in which the 3079 research articles analyzed in relation to Sustainability and Corporate Social Responsibility (CSR) have been framed. In this way, Figure 3 shows the five main topics in which Scopus fits these articles.

In this way, the Business, Management, and Accounting category has been the one that has received the highest number of research papers during the period analyzed, with a total of 1921, which represents $28.35 \%$ of the total. In order of importance, they are followed by Science Social $(1498,22.11 \%)$, Environmental Science (1064, 15.70\%), Economics, Econometrics, and Finance (622, 9.18\%), and Energy (595, 8.78\%). In addition, all these thematic areas have had articles published throughout the analyzed period (2001-2020) by addressing both social and environmental problems, as well as an instrument that favors business development, in a generic way, which indicates the transversality of the research line.

For its part, Table 2 shows the main characteristics of the articles published in the 20 most productive scientific journals during 2001-2020. It stands out that, among these, $65 \%$ are in the first quartile (Q1) of the SJR index in the year 2019. These journals received a total of 1172 articles, which represents $38 \%$ of all articles published in this line of research. 


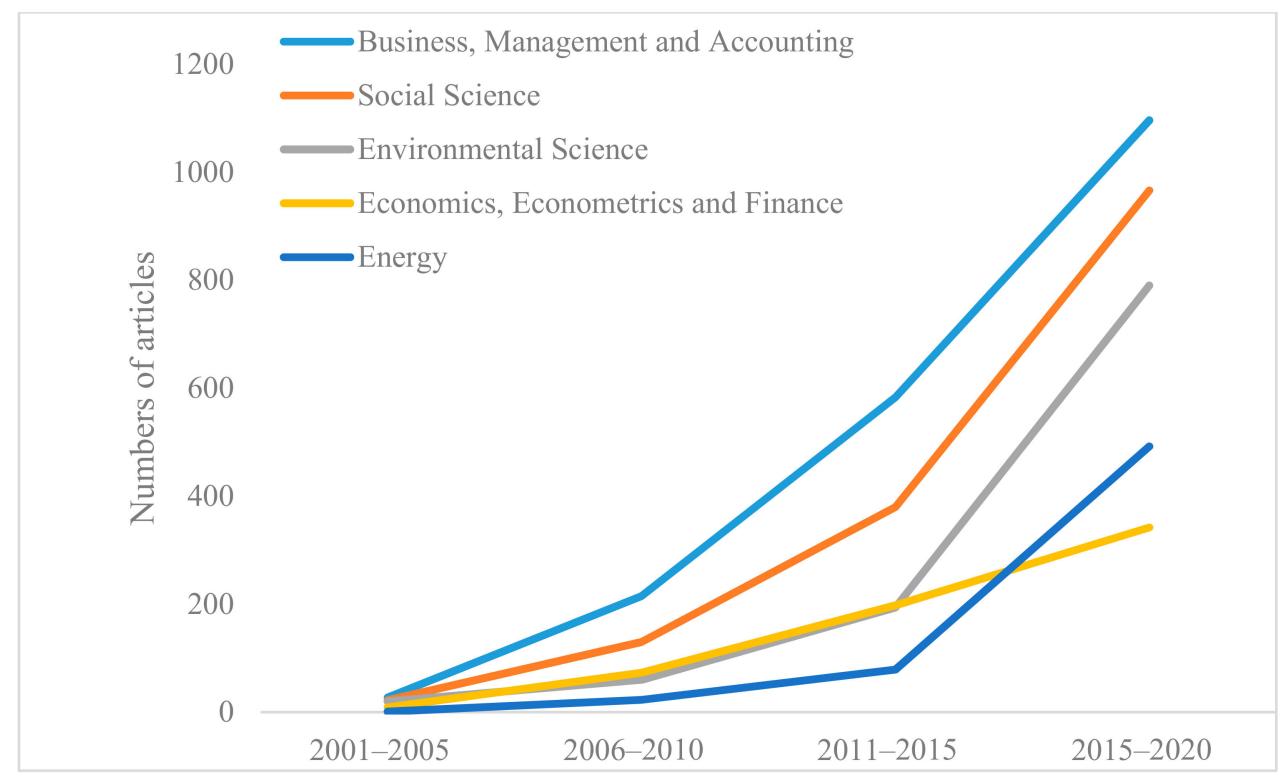

Figure 3. Evolution of the number of articles and exponential variation between periods. Source: own elaboration.

Table 2. Ranking 20 journals with the highest scientific production.

\begin{tabular}{|c|c|c|c|c|c|c|c|c|c|c|c|c|c|}
\hline \multirow{2}{*}{ Journal } & \multirow{2}{*}{ A } & \multirow{2}{*}{ TC } & \multirow{2}{*}{ TC/A } & \multirow{2}{*}{$\begin{array}{l}\text { H-Index } \\
\text { (A) }\end{array}$} & \multirow{2}{*}{ H-Index (J) } & \multirow{2}{*}{ SJR } & \multirow{2}{*}{ c } & \multirow{2}{*}{$\begin{array}{l}\text { First } \\
\text { Article }\end{array}$} & \multirow{2}{*}{$\begin{array}{l}\text { Last } \\
\text { Article }\end{array}$} & \multicolumn{4}{|c|}{$\mathrm{R}(\mathrm{A})$} \\
\hline & & & & & & & & & & 2001-2005 & 2006-2010 & 2011-2015 & 2016-2020 \\
\hline $\begin{array}{l}\text { Sustainability Switzerland } \\
\text { Corporate Social }\end{array}$ & 324 & 2069 & 6.39 & 110 & 68 & $0.581(\mathrm{Q} 2)$ & Switzerland & 2013 & 2020 & 0 & 0 & 14 & 310 \\
\hline $\begin{array}{c}\text { Responsibility and } \\
\text { Environmental Management }\end{array}$ & 164 & 4007 & 24.43 & 44 & 66 & $0.974(\mathrm{Q} 1)$ & UK & 2003 & 2010 & 2 & 10 & 34 & 118 \\
\hline Journal of Cleaner Production & 142 & 6978 & 49.14 & 38 & 173 & $1.886(\mathrm{Q} 1)$ & The Netherlands & 2005 & 2020 & 1 & 5 & 32 & 104 \\
\hline Journal of Business Ethics & 135 & 7231 & 53.56 & 51 & 168 & 1.972 (Q1) & The Netherlands & 2002 & 2020 & 3 & 32 & 50 & 50 \\
\hline $\begin{array}{l}\text { Business Strategy and the } \\
\text { Environment }\end{array}$ & 83 & 2887 & 34.78 & 27 & 94 & $1.828(\mathrm{Q} 1)$ & USA & 2005 & 2020 & 1 & 7 & 18 & 57 \\
\hline $\begin{array}{l}\text { Social Responsibility Journal } \\
\text { Sustainability Accounting }\end{array}$ & 60 & 470 & 7.83 & 21 & 27 & $0.429(\mathrm{Q} 2)$ & UK & 2007 & 2020 & 0 & 10 & 20 & 30 \\
\hline $\begin{array}{l}\text { Management and Policy } \\
\text { Journal }\end{array}$ & 38 & 413 & 10.87 & 10 & 24 & $0.672(\mathrm{Q} 1)$ & UK & 2010 & 2020 & 0 & 4 & 8 & 26 \\
\hline Sustainable Development & 26 & 726 & 27.92 & 7 & 58 & $0.997(\mathrm{Q} 1)$ & USA & 2009 & 2020 & 0 & 5 & 6 & 15 \\
\hline $\begin{array}{l}\text { Organization and } \\
\text { Environment }\end{array}$ & 21 & 569 & 27.10 & 4 & 55 & $2.075(\mathrm{Q} 1)$ & USA & 2013 & 2020 & 0 & 0 & 5 & 16 \\
\hline Corporate Governance Bingley & 20 & 197 & 9.85 & 7 & 53 & $0.574(\mathrm{Q} 2)$ & UK & 2012 & 2020 & 0 & 0 & 9 & 11 \\
\hline $\begin{array}{l}\text { Emerald Emerging Markets } \\
\text { Case Studies }\end{array}$ & 19 & 6 & 0.32 & 4 & 4 & $0.17(\mathrm{Q} 4)$ & UK & 2011 & 2020 & 0 & 0 & 8 & 11 \\
\hline Quality Access to Success & 18 & 39 & 2.17 & 7 & 20 & $0.28(\mathrm{Q} 3)$ & Romania & 2011 & 2020 & 0 & 0 & 7 & 11 \\
\hline Corporate Communications & 16 & 169 & 10.56 & 5 & 52 & $0.627(\mathrm{Q} 2)$ & UK & 2009 & 2020 & 0 & 4 & 3 & 9 \\
\hline Corporate Governance & 16 & 547 & 34.19 & 6 & 78 & $1.471(\mathrm{Q} 1)$ & UK & 2006 & 2011 & 0 & 13 & 3 & 0 \\
\hline $\begin{array}{c}\text { Corporate Ownership and } \\
\text { Control }\end{array}$ & 16 & 40 & 2.50 & 6 & 18 & $0.148(\mathrm{Q} 4)$ & Ukraine & 2009 & 2016 & 0 & 1 & 13 & 2 \\
\hline Journal of Business Research & 16 & 430 & 26.88 & 6 & 179 & $1.871(\mathrm{Q} 1)$ & The Netherlands & 2013 & 2020 & 0 & 0 & 4 & 12 \\
\hline $\begin{array}{l}\text { Accounting Auditing and } \\
\text { Accountability Journal }\end{array}$ & 15 & 608 & 40.53 & 5 & 92 & $1.459(\mathrm{Q} 1)$ & UK & 2007 & 2020 & 0 & 4 & 4 & 7 \\
\hline $\begin{array}{l}\text { Entrepreneurship and } \\
\text { Sustainability Issues }\end{array}$ & 15 & 117 & 7.80 & 7 & 18 & $1.171(\mathrm{Q} 1)$ & Lithuania & 2017 & 2020 & 0 & 0 & 0 & 15 \\
\hline Business and Society & 14 & 471 & 33.64 & 6 & 70 & $1.796(\mathrm{Q} 1)$ & USA & 2008 & 2020 & 0 & 2 & 1 & 11 \\
\hline Journal of Sustainable Tourism & 14 & 314 & 22.43 & 4 & 93 & $1.333(\mathrm{Q} 1)$ & UK & 2008 & 2020 & 0 & 2 & 2 & 10 \\
\hline
\end{tabular}

(J): journals; (A): number of articles; (TC): number of citations; (TC/A): an average of citations per article; (H) (A) H-index of the articles; (H) (J): H-index of the journal; (SJR); Scimago Journal Rank (quartile); (C): country; (R); the rank of position by the number of articles in the analyzed five-year period (number of articles published in that same five-year period).

It is observed that the highest impact index is the one presented by Organization and Environment with 2075 (Q1), followed by Journal of Business Ethics with 1972 (Q1). Regarding the number of articles received, Sustainability has been the most productive (324; 27.65\%), followed by Corporate Social Responsibility and Environmental Management (164; $13.99 \%$ ) and Journal of Cleaner Production (142; 12.12\%). On the other hand, Corporate Social Responsibility and Environmental Management, Journal of Cleaner Production, Journal of Business Ethics (it is also the oldest in the research area-first publication in 2002), Business Strategy and the Environment are the only four journals that have published scientific articles during the four decades analyzed, while Corporate Governance is the only one that has not received articles on this line of research in the last five years. This is a clear sign that the research topic has been attracting the attention of the research community and, therefore, of scientific journals. 
Sustainability Switzerland is the journal that has received the highest number of articles (324), of which 310 have been published during the last five years, and it is also the journal with the highest $\mathrm{H}$-index in the research area (110). However, it is the Journal of Business Research, the journal with the highest H-index (179). For its part, the Journal of Business Ethics is the scientific journal with the highest average number of citations per article (53.56).

Finally, it should be noted that $80 \%$ of the most productive scientific journals belong to member countries of the European Union, while the remaining $20 \%$ are in the US, and there are no journals among the 20 most productive of the rest of the continents.

\subsubsection{Author Productivity}

This section aims to show the authors with higher productivity, as well as the cooperation between them based on the indicator of co-authorship. Thus, Table 3 shows the main variables analyzed of the 10 most productive researchers in the areas of knowledge about Sustainability and Corporate Social Responsibility (CSR) during the period between 2001 and 2020. It stands out that all the authors who present higher productivity in the research area are of European origin, of which 50\% are of Spanish origin, with the remaining 50\% of different nationalities.

Table 3. Most productive authors.

\begin{tabular}{|c|c|c|c|c|c|c|c|c|}
\hline Authors & A & TC & TC/A & Institution & $\mathrm{C}$ & First A & Last A & H-Index \\
\hline García-Sánchez, I.M. & 21 & 647 & 30.81 & Universidad de Salamanca & Spain & 2010 & 2020 & 5 \\
\hline Font, $X$ & 9 & 485 & 53.89 & University of Surrey & UK & 2004 & 2020 & 5 \\
\hline Martínez-Ferrero, J. & 9 & 205 & 22.78 & Universidad de Salamanca & Spain & 2014 & 2020 & 2 \\
\hline Moratis, L. & 9 & 82 & 9.11 & Breda University of Applied Sciences & The Netherlands & 2014 & 2018 & 2 \\
\hline Nikolaou, I.E. & 9 & 241 & 26.78 & Democritus University of Thrace & Greece & 2009 & 2020 & 1 \\
\hline Schaltegger, S. & 9 & 769 & 85.44 & Leuphana Universität Lüneburg & Germany & 2012 & 2020 & 3 \\
\hline Seele, $\mathrm{P}$. & 9 & 285 & 31.67 & Università della Svizzera Italiana & Switzerland & 2014 & 2020 & 3 \\
\hline Fernandez-Feijoo, B. & 9 & 376 & 41.78 & Universidad de Vigo & Spain & 2014 & 2020 & 3 \\
\hline Moneva, J.M. & 8 & 270 & 33.75 & Universidad de Zaragoza & Spain & 2007 & 2018 & 3 \\
\hline Rodríguez-Ariza, L. & 8 & 332 & 41.50 & Universidad de Granada & Spain & 2013 & 2020 & 2 \\
\hline
\end{tabular}

(A): number of articles; (TC) number of citations; (C): country; (TC/A): an average number of citations per article; (H-index): Hirsch index in this research area; (First A): first article; (Last A); last article.

The most productive author is García-Sánchez, with a total of 22 articles published during the period of time analyzed (2001-2020), followed by Font, X. with a total of nine research articles, who is also the author most incipient of the ten most productive, when publishing her first article on the subject in 2004. Despite the fact that the first author has the highest number of citations (647), both share the same quality indication in the area of research (H-index 5).

For its part, Schaltegger, S., from Leuphana Universität Lüneburg, is the author with the highest average number of citations (84.44). Finally, of the ten most productive authors, only Moratis, L. and Moneva, J.M. have not published research articles in the research area in 2020.

Lastly, Figure 4 shows the collaboration map between the main authors who have published on Sustainability and Corporate Social Responsibility (CSR), based on the coauthorship analysis. The colors show the working groups, while the size of the circle varies according to the number of articles published by each author. The network shows a great dispersion, which could favor the rapid growth of the research area, since, among the most productive authors, only the Greek Nikolaou seems to have a stable international network of work. As for the rest of the most productive authors, Zhang also appears to develop an international collaboration network on Sustainability and Corporate Social Responsibility (CSR). 
\& VOSviewer

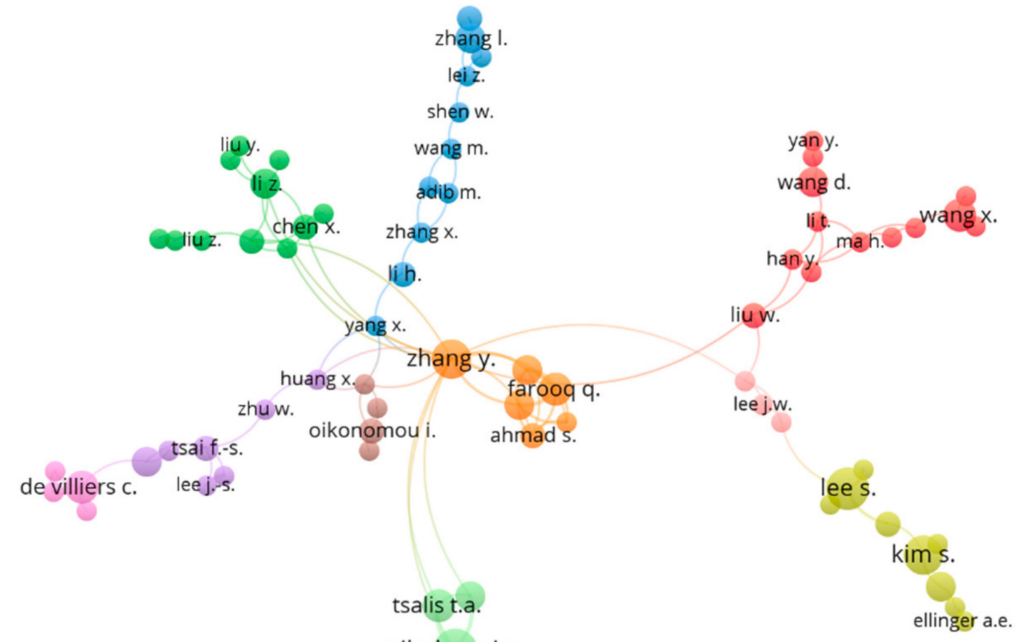

Figure 4. The network of cooperation, based on the co-authorship of the main author.

\subsubsection{Productivity of Countries and Institutions}

This section aims to show the most productive institutions and countries, as well as the rates of cooperation and the cooperation network based on co-authorship and the most fruitful international collaborations. In this way, Table 4 shows the 10 most productive institutions in terms of Sustainability and Corporate Social Responsibility (CSR) in the period between 2001 and 2020. It is clearly seen in the classification that $90 \%$ of the most productive institutions are of European origin, except for the Universiti Teknologi MARA (Malaysia), which is of Asian origin.

Table 4. Ranking of the 10 most productive institutions.

\begin{tabular}{|c|c|c|c|c|c|c|c|c|}
\hline & & & & & & & \multicolumn{2}{|c|}{ TC/A } \\
\hline Institution & $\mathrm{C}$ & A & TC & TC/A & H-Index & IC (\%) & IC & NIC \\
\hline Universidad de Salamanca & Spain & 38 & 1101 & 28.97 & 10 & $28.9 \%$ & 10.55 & 36.48 \\
\hline Bucharest University of Economic Studies & Romania & 28 & 161 & 5.75 & 10 & $10.7 \%$ & 2.33 & 6.16 \\
\hline Universidad de Granada & Spain & 27 & 1177 & 43.59 & 6 & $25.9 \%$ & 11.00 & 55.00 \\
\hline Leuphana Universität Lüneburg & Germany & 26 & 1324 & 50.92 & 6 & $30.8 \%$ & 20.13 & 64.61 \\
\hline Wageningen University and Research & The Netherlands & 25 & 356 & 14.24 & 6 & $48.0 \%$ & 12.67 & 15.69 \\
\hline Universidad de Valencia & Spain & 24 & 330 & 13.75 & 5 & $37.5 \%$ & 5.44 & 18.73 \\
\hline Universitat Politècnica de València & Spain & 21 & 133 & 6.33 & 6 & $19.0 \%$ & 4.75 & 6.71 \\
\hline Universidad de Zaragoza & Spain & 21 & 492 & 23.43 & 7 & $23.8 \%$ & 18.80 & 24.88 \\
\hline Copenhagen Business School & Denmark & 20 & 931 & 46.55 & 6 & $45.0 \%$ & 39.89 & 52.00 \\
\hline Universiti Teknologi MARA & Malaysia & 17 & 383 & 22.53 & 5 & $35.3 \%$ & 48.83 & 8.18 \\
\hline
\end{tabular}

(C): country; (A): number of articles; (TC) number of citations; (TC/A): an average number of citations per article; (H-index): Hirsch index in this research area; (IC\%): percentage of articles produced with international collaboration; (IC): number of citations per article made with international collaboration; (NIC): number of citations per article made without international collaboration.

The University of Salamanca (Spain) is the most productive institution with 38 articles published in the period analyzed, followed by the Bucharest University of Economic Studies (Romania) with 28 published articles, although both share the same H-index of 10. Leuphana Universität Lüneburg (Germany) is the institution with the highest number of citations (1324), followed by the University of Granada (1177).

On the other hand, it is observed that a high number of institutions have a low rate of international cooperation, with the exception of Wageningen University and Research (The Netherlands) and Copenhagen Business School (Denmark), the only institutions 
with a cooperation rate of more than $40 \%$. That is why $90 \%$ of the institutions have a higher average of citations in those articles that are not published in co-authorship with researchers who are from their own country of origin, with the exception of the Universiti Teknologi MARA (48.33 compared to 8.18).

For its part, Table 5 shows the most productive countries in terms of Sustainability and Corporate Social Responsibility (CSR) during the period analyzed. In this case, the origin is much more dispersed, although Europe predominates, with $50 \%$ of countries of European origin (Spain, United Kingdom, Italy, Germany, and The Netherlands), followed by $20 \%$ of American origin (USA and Canada), 20\% Asian (China and India), and 10\% oceanic (Australia).

Table 5. Ranking of the most productive countries in the number of articles.

\begin{tabular}{|c|c|c|c|c|c|c|c|c|}
\hline \multirow{2}{*}{ Country } & \multirow{2}{*}{ A } & \multirow{2}{*}{ TC } & \multirow{2}{*}{ TC/A } & \multirow{2}{*}{ H-Index } & \multicolumn{4}{|c|}{$\mathbf{R}(\mathrm{A})$} \\
\hline & & & & & 2001-2005 & 2006-2010 & 2011-2015 & 2016-2020 \\
\hline United States & 466 & 16,312 & 35.00 & 103 & $2(7)$ & $1(60)$ & $1(162)$ & $1(237)$ \\
\hline Spain & 347 & 6591 & 18.99 & 76 & $4(2)$ & $4(18)$ & $3(103)$ & $2(224)$ \\
\hline United Kingdom & 332 & 8809 & 26.53 & 83 & $1(14)$ & $2(42)$ & 2 (109) & $3(167)$ \\
\hline Italy & 204 & 2619 & 12.84 & 67 & $6(1)$ & $9(6)$ & $8(37)$ & $4(160)$ \\
\hline Australia & 174 & 4123 & 23.70 & 39 & $6(1)$ & $3(33)$ & $4(56)$ & $8(84)$ \\
\hline China & 159 & 1528 & 9.61 & 47 & $10(0)$ & $10(4)$ & $10(21)$ & $5(134)$ \\
\hline India & 148 & 1089 & 7.36 & 35 & $6(1)$ & $8(7)$ & $9(22)$ & $6(118)$ \\
\hline Germany & 146 & 4122 & 28.23 & 34 & $6(1)$ & $7(13)$ & $6(40)$ & $7(92)$ \\
\hline Canada & 133 & 4988 & 37.50 & 35 & $4(2)$ & $6(14)$ & $5(44)$ & $9(73)$ \\
\hline The Netherlands & 118 & 3909 & 33.13 & 28 & $3(5)$ & $5(15)$ & $7(38)$ & $10(60)$ \\
\hline
\end{tabular}

(A): number of articles; (R): position rank by number of articles in the four-year period; (TC): number of citations; (TC/A): number of citations per article; (H-index): Hirsch index on the research topic.

The United States is the country with the highest number of articles (466), followed by Spain (347) and the United Kingdom (332). The United States is also the country with the highest number of citations $(16,312)$ and the highest H-index (103), which makes it the second country with the highest average number of citations (35), only behind Canada (37.50).

With regard to the evolution of the research topic, the United Kingdom is the country with the highest scientific production of research articles in the first five years analyzed (14 scientific articles), followed by the United States (7). However, in the following decades, the United States has always been the most productive country. In the case of Spain, it remains in the Top-4 during the four decades analyzed, although the significant increase in articles in the last period (224) allows it to become the second most productive country today. Like Spain, all the countries that are among the most productive have significantly increased their scientific production in the last five years (2016-2020), especially the countries of Asian origin, which have multiplied their publications by six.

For its part, Table 6 shows the international cooperation networks, as well as the main indicators of evolution, of the most productive countries in the research area and the temporality analyzed.

China is the country with the highest international collaboration $(71.1 \%)$, followed by the United Kingdom (53.6\%), which is also the country with the highest number of international collaborators (62). The rest of the countries, among the most productive, have an international collaboration percentage of less than 50\%. Likewise, the Netherlands, Italy, India, and China have a higher average of citations in international networks.

As for the institutions, a major predisposition is found in the case of Asian countries to establish international collaborations, obtaining major quality indexes.

Finally, Figure 5 shows the collaboration map between the main countries based on co-authorship. Colors show international working groups, and circle size varies based on the number of items. Thus, the red cluster is the one with the largest number of countries (14) and is led by Italy. It is followed by the green cluster, with 12 countries, including the United Kingdom, Germany, and The Netherlands, as well as the blue cluster, with a total of 
11 countries, which are led by Australia and Canada. Finally, the United States is included in the yellow cluster, with a total of 10 countries, among which is China, while Spain is in the smallest cluster, purple, with a total of five countries.

Table 6. Most productive countries and their international collaboration.

\begin{tabular}{|c|c|c|c|c|c|}
\hline \multirow{2}{*}{ Country } & \multirow{2}{*}{ NC } & \multirow{2}{*}{ Main Collaborators } & \multirow{2}{*}{ IC (\%) } & \multicolumn{2}{|c|}{ TC/A } \\
\hline & & & & IC & NIC \\
\hline United States & 54 & United Kingdom, Canada, China, France, Spain & $38.6 \%$ & 32.28 & 36.72 \\
\hline Spain & 43 & Portugal, United States, Mexico, United Kingdom, Italy & $34.0 \%$ & 15.38 & 20.86 \\
\hline United Kingdom & 62 & United States, China, Italy, France, Germany & $53.6 \%$ & 25.61 & 27.60 \\
\hline Italy & 34 & United Kingdom, United States, Spain, Denmark & $33.3 \%$ & 14.37 & 12.07 \\
\hline Australia & 33 & United Kingdom, China, United States, Indonesia, Malaysia & $33.9 \%$ & 14.36 & 28.49 \\
\hline China & 47 & United Kingdom, United States, Pakistan, Hong Kong & $71.1 \%$ & 10.21 & 8.13 \\
\hline India & 23 & United States, United Kingdom, Italy, France, Mexico & $20.9 \%$ & 11.42 & 6.28 \\
\hline Germany & 34 & United Kingdom, United States, France, Switzerland, Austria & $42.5 \%$ & 20.79 & 33.73 \\
\hline Canada & 30 & United States, United Kingdom, France, Brazil, China & $49.6 \%$ & 31.59 & 43.33 \\
\hline The Netherlands & 27 & Belgium, United Kingdom, United states, Finland, France & $42.4 \%$ & 37.08 & 30.22 \\
\hline
\end{tabular}

(NC): number of collaborative countries; (IC): percentage of countries in collaborative papers; (TC/A): number of citations per article; (IC): international cooperation; (NIC): no international cooperation.

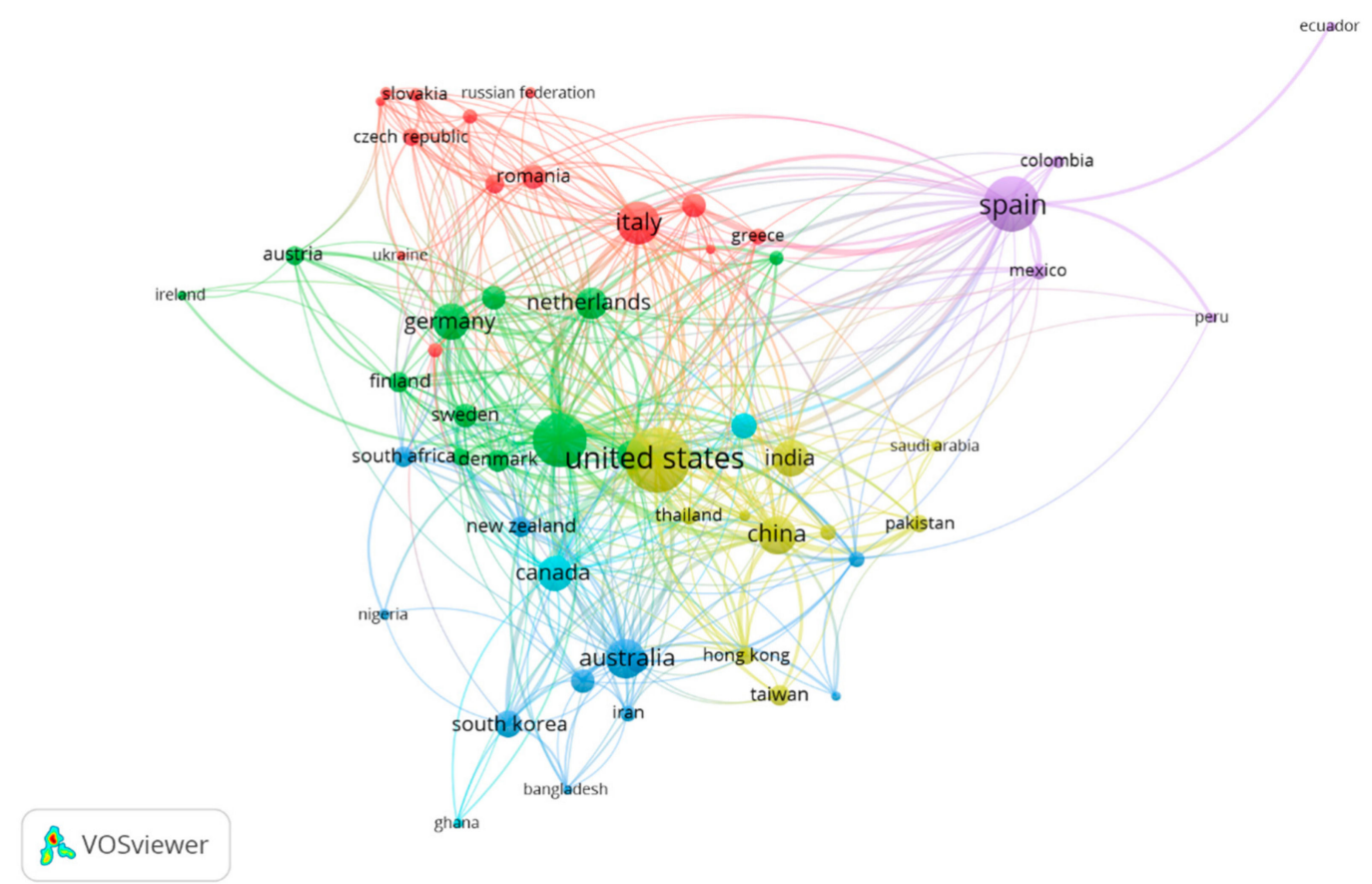

Figure 5. International cooperation, based on the co-authorship between countries.

\subsection{Keyword Analysis}

For the total of 3079 articles analyzed on Sustainability and Corporate Social Responsibility (CSR) in the period between 2001 and 2020, a total of 8898 keywords have been obtained. Of these, Table 7 lists the 20 considered most relevant by the authors since they allow us to disaggregate the interests that have been generated in the research line, based on the dimensions cited in the contextualization, throughout the period analyzed.

In this way, five thematic axes have been differentiated. The first of them, on "Sustainability and CSR", to know the evolution of the dimensions that compose it. We found that "Sustainable Development" is a very transversal concept since it appears in 652 research papers (21.2\% of the total), while the social, environmental, and economic dimensions separately have appeared in a lower number of articles, although they have been maintained in all periods. 
Table 7. Keywords in sustainability and CSR.

\begin{tabular}{|c|c|c|c|c|c|c|c|c|c|c|c|}
\hline \multirow{2}{*}{ Group } & \multirow{2}{*}{ Keyword } & \multicolumn{2}{|c|}{ 2001-2020 } & \multicolumn{2}{|c|}{ 2001-2005 } & \multicolumn{2}{|c|}{ 2006-2010 } & \multicolumn{2}{|c|}{ 2011-2015 } & \multicolumn{2}{|c|}{ 2016-2020 } \\
\hline & & $\mathbf{A}$ & $\%$ & A & $\%$ & $\mathbf{A}$ & $\%$ & $\mathbf{A}$ & $\%$ & A & $\%$ \\
\hline \multirow{4}{*}{ Sustainability and CSR } & Sustainable Development & 652 & $21.2 \%$ & 11 & $22.4 \%$ & 73 & $24.1 \%$ & 177 & $20.6 \%$ & 391 & $20.9 \%$ \\
\hline & Environmental Sustainability & 63 & $2.0 \%$ & 2 & $4.1 \%$ & 5 & $1.7 \%$ & 17 & $2.0 \%$ & 39 & $2.1 \%$ \\
\hline & Economic Sustainability & 29 & $0.9 \%$ & 1 & $2.0 \%$ & 15 & $5.0 \%$ & 5 & $0.6 \%$ & 8 & $0.4 \%$ \\
\hline & Social Sustainability & 28 & $0.9 \%$ & 1 & $2.0 \%$ & 2 & $0.7 \%$ & 5 & $0.6 \%$ & 20 & $1.1 \%$ \\
\hline \multirow{4}{*}{ Environmental } & Environmental Performance & 36 & $1.2 \%$ & 1 & $2.0 \%$ & 2 & $0.7 \%$ & 10 & $1.2 \%$ & 23 & $1.2 \%$ \\
\hline & Circular Economy & 21 & $0.7 \%$ & 0 & $0 \%$ & 0 & $0 \%$ & 0 & $0 \%$ & 21 & $1.1 \%$ \\
\hline & Environment & 52 & $1.7 \%$ & 1 & $2.0 \%$ & 9 & $3.0 \%$ & 15 & $1.7 \%$ & 27 & $1.4 \%$ \\
\hline & Environmental Economics & 81 & $2.6 \%$ & 2 & $4.1 \%$ & 4 & $1.3 \%$ & 19 & $2.2 \%$ & 56 & $3.0 \%$ \\
\hline \multirow{4}{*}{ Economics and Finance } & Performance Assessment & 67 & $2.2 \%$ & 1 & $2.0 \%$ & 2 & $0.7 \%$ & 12 & $1.4 \%$ & 52 & $2.8 \%$ \\
\hline & Financial Performance & 66 & $1.0 \%$ & 1 & $2.0 \%$ & 4 & $1.3 \%$ & 14 & $1.6 \%$ & 47 & $2.5 \%$ \\
\hline & Profitability & 39 & $1.3 \%$ & 0 & $0 \%$ & 0 & $0 \%$ & 7 & $0.8 \%$ & 32 & $1.7 \%$ \\
\hline & Socially Responsible Investment & 19 & $0.6 \%$ & 0 & $0 \%$ & 0 & $0 \%$ & 11 & $1.3 \%$ & 7 & $0.4 \%$ \\
\hline \multirow{4}{*}{ Social } & Economic and Social Effects & 123 & $4.0 \%$ & 6 & $12.2 \%$ & 9 & $3.0 \%$ & 30 & $3.5 \%$ & 78 & $4.2 \%$ \\
\hline & Ethics & 92 & $3.0 \%$ & 1 & $2.0 \%$ & 6 & $2.0 \%$ & 36 & $4.2 \%$ & 49 & $2.6 \%$ \\
\hline & Human Rights & 26 & $0.8 \%$ & 0 & $0 \%$ & 4 & $1.3 \%$ & 5 & $0.6 \%$ & 17 & $0.9 \%$ \\
\hline & Social Entrepreneurship & 18 & $0.6 \%$ & 1 & $2.0 \%$ & 0 & $0 \%$ & 5 & $0.6 \%$ & 12 & $0.6 \%$ \\
\hline \multirow{4}{*}{ Communication } & Communication & 32 & $1.0 \%$ & 0 & $0 \%$ & 3 & $1.0 \%$ & 8 & $0.9 \%$ & 21 & $1.1 \%$ \\
\hline & Marketing & 25 & $0.8 \%$ & 0 & $0 \%$ & 0 & $0 \%$ & 5 & $0.6 \%$ & 20 & $1.1 \%$ \\
\hline & CSR Reporting & 31 & $1.0 \%$ & 0 & $0 \%$ & 0 & $0 \%$ & 11 & $1.3 \%$ & 20 & $1.1 \%$ \\
\hline & Sustainability Reporting & 134 & $4.4 \%$ & 1 & $2.0 \%$ & 10 & $3.3 \%$ & 37 & $4.3 \%$ & 86 & $4.6 \%$ \\
\hline
\end{tabular}

(A): number of papers where keywords concur.

The second, to know the "Environmental" dimension. "Environmental Economics" stands out in a total of 81 research papers, experiencing constant growth throughout the analyzed period (2001-2020). Likewise, the strong emergence of "Circular Economy" stands out, which, although it did not do so until five years 2016-2020, has been present in 21 research papers.

In the third place, the "Economics and Finance" dimension highlights the growth of the "Performance Assessment" topics, present in $4.2 \%$ of the last period analyzed (2016-2020), as well as the strong inclusion of "Profitability" (39 research articles).

Regarding the "Social" dimension, "Economic and Social Effects" has been a frequently used recurring topic throughout the period ( $4 \%$ of the total articles published), while the strong increase in "Ethics" stands out, which, although it appears vaguely in the period $2001-2005$, is present in $3 \%$ of the articles published due to the subsequent strong increase.

Finally, the "Communication" dimension is analyzed as an instrument available to organizations to publicize their CSR and Sustainability practices. It stands out how until practically five years 2011-2015, they did not appear in the research articles, to later gradually increase, especially "Sustainability Reporting", until it was present in $4.4 \%$ of the total research papers published between 2001 and 2020.

For its part, the relationship between all the keywords in the sample is observed in Figure 6. This grouping is based on the co-occurrence method used by the VOSviewer application when analyzing the simultaneity of keywords in the articles in the sample. Thus, the color of the nodes is used to distinguish the different clusters according to the number of co-occurrences, while their size varies according to the number of repetitions. For the selection of keywords, those that have at least 15 interactions have been identified, finally identifying 193 keywords. Thus, six clusters of different colors are observed, which could be associated with different lines of research in the subject under study, although it is clear that it is a very transversal line of research, finding interrelations among every keyword we found: 'Sustainable development', 'Stakeholders', 'Sustainability report', 'Stakeholder engagement', 'Business ethics', and 'Supply chain management'.

In the first place, the red cluster refers to the importance of the "Stakeholders" and is made up of 33 items. Second, the green cluster is linked to "Sustainable Development" from a broad dimension, being composed of 29 items. Next, the blue cluster, which refers to "Decision Making", is made up of a total of 23 items. The yellow cluster is linked to "Business Ethics", with a total of 23 items. On the other hand, the purple cluster is 
associated with "Communication", with a total of 13 items. Finally, the light blue cluster has a direct link with the "Business Strategy" and is made up of 11 items.

\& VOSviewer

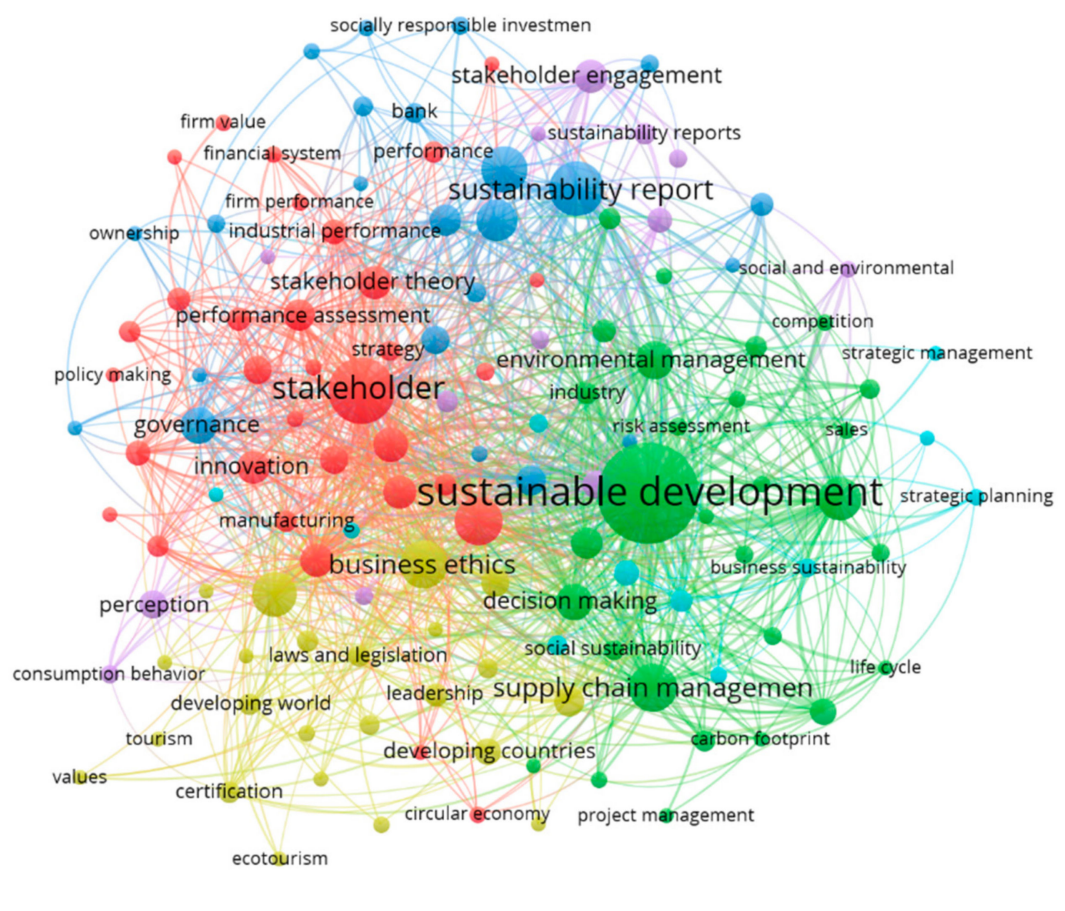

Figure 6. Keyword clustering based on co-occurrence.

Finally, Figure 7 shows the main research trends in recent years, thus establishing the main lines of research today and in the coming years.

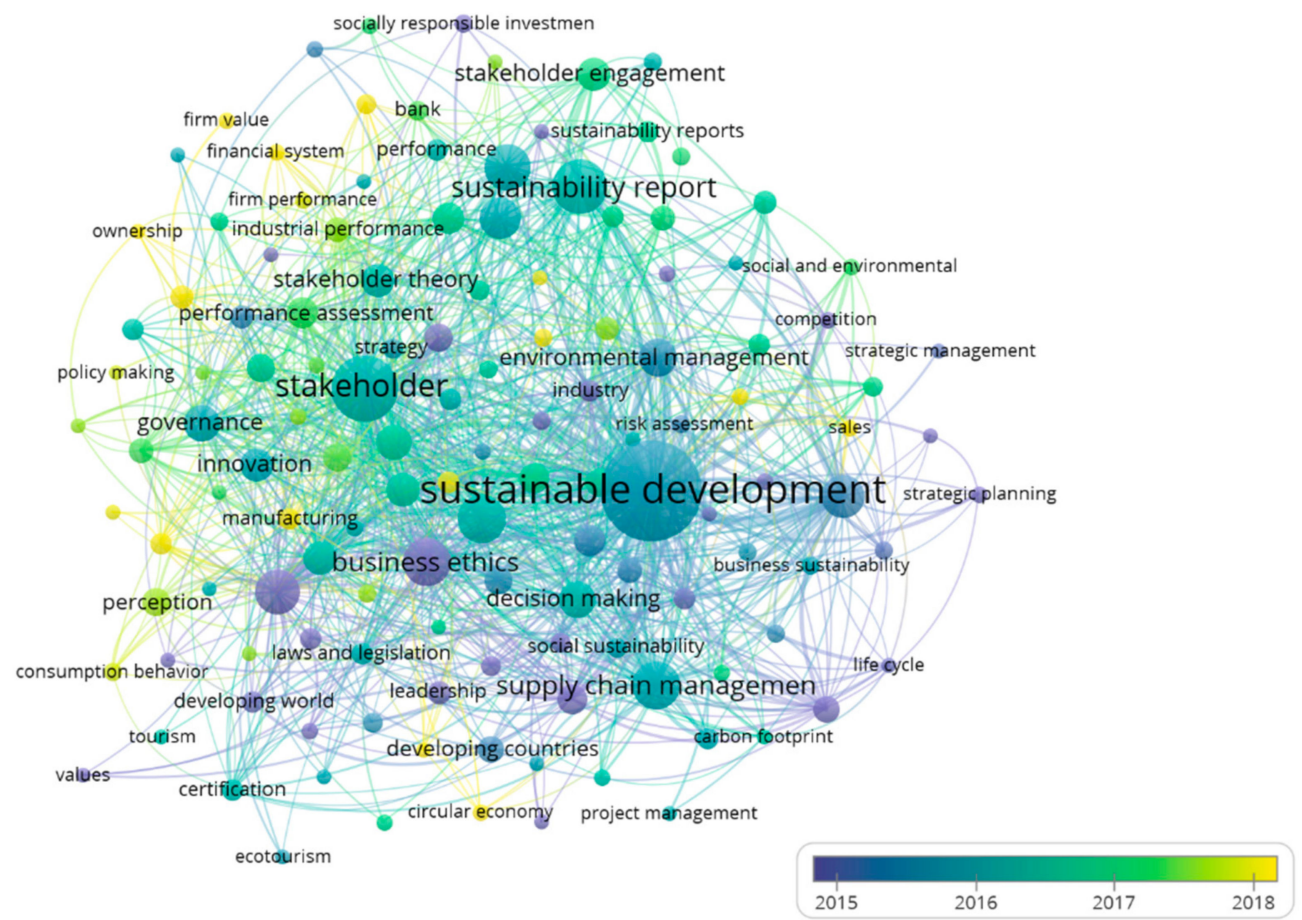

Figure 7. Evolution of keyword clusters based on co-occurrence. 
Thus, within the "Stakeholders" cluster, trends are mainly oriented to brand image, human resources management, and supply chain management. For its part, "Sustainable Development" has as main research trends the management of the supply chain, as well as socially responsible investments. On the other hand, "Decision Making" is not currently being considered as a line of interest, while "Business Ethics" is working intensively on community development and new economic paradigms, such as the Circular Economy. Finally, "Communication" is paying attention primarily to the perception of interest groups and consumer behavior, and "Business Strategy" has no new research trends.

\section{Conclusions}

The objective of this study has been to analyze the evolution of research articles on CSR and Sustainability at a global level in the period between 2001 and 2020. For this, bibliometric analysis has been carried out on 3079 research articles in the database Scopus.

Primarily, the general analysis of the research shows exponential growth in the interest of the scientific community, derived from the continuous growth of articles, authors, and citations. We may also highlight the increase in the number of scientific journals, countries, and institutions motivated, in the last 5 years, to the interest in analyzing the implications of achieving the Sustainable Development Goals (SDG).

Regarding the analysis of the authors, the researcher García-Sánchez has been the most relevant of the entire period analyzed, with 22 research articles published, despite starting to work on the line of research as of 2010. From this analysis, the importance of European researchers is also clear, who make up the Top-10 of the most productive, among which five are of Spanish nationality.

The analysis of the thematic areas of research shows that during the entire period analyzed, "Business, Management, and Accounting" has been the main one (28.35\%), followed by "Social Science" (22.11\%) and "Environmental Science" $(15.70 \%)$, with these three subject areas making $66.16 \%$ of the publications.

In terms of scientific journals, Sustainability Switzerland has been the most productive during the period between 2001 and 2020, despite the fact that it began to publish research articles on the subject of CSR and Sustainability in the period 2011-2015. For its part, Organization and Environment is the one with the highest H-index (2075 (Q1)), despite the fact that it has received a reduced number of articles (21). For its part, the Journal of Business Ethics is the one with the highest average number of citations per article (56.56\%).

Regarding the institutions, as with the authors, those of European origin predominate $(90 \%)$, especially those of Spanish nationality $(50 \%)$, with the University of Salamanca being the most productive ( 38 research works). All the institutions analyzed show results below $50 \%$ in terms of the cooperation rate. A similar situation occurs with the analysis of countries whose cooperation rates are also lower than $50 \%$, with the exception of China and the United Kingdom. In this case, although there is greater diversity in terms of nationality, countries of European origin continue to predominate $(50 \%)$, although the United States is the country with the highest production (466 articles published).

Likewise, it has been identified that the implementation of CSR and Sustainability policies has the main lines of research as "Stakeholders", "Sustainable Development", "Decision Making", "Business Ethics", "Communication", "Business Strategy", which they act transversally to the economic, social, and environmental dimensions. From these lines, future lines of research have been detected, such as the value of the brand, determined by the participation of the stakeholders of the strategy and communication, as well as the emergence of new business paradigms, such as the circular economy.

Concerning the implications of this proposal, as said before, the continuous growth of articles, authors, countries, citations, and scientific journals, motivated by the publication of the Green Book and the ISO 26000 Standard, has been displayed in the last decades. Sustainable Development Goals (SDG's) and 2030 Agenda may motivate practitioners and researchers to broaden their perspectives to approach the implications between CSR and Sustainability. Moreover, the relevance of the 17 SDGs should be highlighted, 
which suggests the importance of strengthening the global partnership for sustainable development. Precisely, in order to understand and measure the suitability of the variety of multi-stakeholders who mobilize and share knowledge and expertise, a bibliometric analysis gives clues and establishes links among clusters and pertinent lines in the future.

Finally, this work has some limitations, which could be the basis for future research, and which would be derived from the fact that it is a quantitative analysis, so qualitative aspects are not considered, which, together with the use of other computer tools from data analysis, might provide slightly different results. In the same way, the analysis has focused exclusively on the publication of scientific articles during the period 2001-2020, not considering participation in Congresses, book publications, or book chapters, among others, as well as another time horizon. In this way, incorporating a greater diversity of research material could lead to different results. Among the lines of research to be developed in the future, it would be interesting to study (i) CSR and Sustainable Development Goals; (ii) advances in the social dimension; (iii) Circular Economy and Social Sustainability.

Author Contributions: Conceptualization, V.M.-S., F.J.G.-S., G.L.-M., and V.M.-M.; methodology V.M.-S., F.J.G.-S., G.L.-M., and V.M.-M.; software, F.J.G.-S.; validation, V.M.-S., F.J.G.-S., G.L.-M., and V.M.-M.; formal analysis, V.M.-S., F.J.G.-S., G.L.-M., and V.M.-M.; investigation, V.M.-S., F.J.G.-S., G.L.-M., and V.M.-M.; resources, V.M.-S., F.J.G.-S., G.L.-M., and V.M.-M.; data curation, F.J.G.-S. and V.M.-M.; writing—original draft preparation, V.M.-S., F.J.G.-S., G.L.-M., and V.M.-M.; writing—review and editing, V.M.-S., F.J.G.-S., G.L.-M., and V.M.-M.; visualization, V.M.-S., F.J.G.-S., G.L.-M., and V.M.-M.; supervision, V.M.-S. and V.M.-M.; project administration, V.M.-S., F.J.G.-S., G.L.-M., and V.M.-M. All authors have read and agreed to the published version of the manuscript and have contributed substantially to the work reported.

Funding: This research received no external funding.

Institutional Review Board Statement: Not applicable.

Informed Consent Statement: Not applicable.

Data Availability Statement: Data sharing not applicable.

Conflicts of Interest: The authors declare no conflict of interest.

\section{References}

1. World Commission on Environment and Development (WCED). Our Common Future; Oxford University Press: New York, NY, USA, 1987.

2. United Nations. Agenda 21. In Proceedings of the United Nations Conference on Environment and Development, Rio de Janeiro, Brazil, 3-14 June 1992.

3. United Nations. The Millenium Development Goals Report 2005; United Nations: New York, NY, USA, 2005.

4. United Nations. The Sustainable Development Goals Report; United Nations Publ.: New York, NY, USA, 2017. [CrossRef]

5. Kates, R.W.; Parris, T.M.; Leiserowitz, A.A. What is sustainable development? Goals, indicators, values, and practice. Environment 2005, 47. [CrossRef]

6. Reyes-Menendez, A.; Saura, J.R.; Alvarez-Alonso, C. Understanding \#worldenvironmentday user opinions in twitter: A topicbased sentiment analysis approach. Int. J. Environ. Res. Public Health 2018, 15, 2537. [CrossRef]

7. Hutchins, M.J.; Sutherland, J.W. An exploration of measures of social sustainability and their application to supply chain decisions. J. Clean. Prod. 2008, 16. [CrossRef]

8. Gimenez, C.; Sierra, V.; Rodon, J. Sustainable operations: Their impact on the triple bottom line. Int. J. Prod. Econ. 2012, 140. [CrossRef]

9. Commission of the European Communities. Implementing the Partnership for Growth and Jobs: Making Europe a Pole of Excellence on Corporate Social Responsibility; Commission of the European Communities: Brussels, Belgium, 2006.

10. Linton, J.D.; Klassen, R.; Jayaraman, V. Sustainable supply chains: An introduction. J. Oper. Manag. 2007, 25. [CrossRef]

11. Nicolăescu, E.; Alpopi, C.; Zaharia, C. Measuring corporate sustainability performance. Sustainability 2015, 7, 851. [CrossRef]

12. Carroll, A.B. The pyramid of corporate social responsibility: Toward the moral management of organizational stakeholders. Bus. Horiz. 1991, 34. [CrossRef]

13. Rodriguez, P.; Siegel, D.S.; Hillman, A.; Eden, L. Three lenses on the multinational enterprise: Politics, corruption, and corporate social responsibility. J. Int. Bus. Stud. 2006, 37, 733-746. [CrossRef]

14. Portney, P.R. The (Not So) new corporate social responsibility: An empirical perspective. Rev. Environ. Econ. Policy 2008, 2. [CrossRef] 
15. Matten, D.; Moon, J. "Implicit" and "explicit" CSR: A conceptual framework for a comparative understanding of corporate social responsibility. Acad. Manag. Rev. 2008. [CrossRef]

16. Colantonio, A. Social sustainability: A review and critique of traditional versus emerging themes and assessment methods. In Proceedings of the Sue-Mot Conference, Second International Conference on Whole Life Urban Sustainability and Its Assessment, Loughborough, UK, 22-24 April 2009.

17. Lozano, R.; Huisingh, D. Inter-linking issues and dimensions in sustainability reporting. J. Clean. Prod. 2011, 19. [CrossRef]

18. Boström, M. The problematic social dimension of sustainable development: The case of the Forest Stewardship Council. Int. J. Sustain. Dev. World Ecol. 2012, 19. [CrossRef]

19. Landorf, C. Evaluating social sustainability in historic urban environments. Int. J. Herit. Stud. 2011, 17. [CrossRef]

20. McKenzie, S. Working Paper Series No 27 Social Sustainability: Towards Some Definitions; University of South Australia: Adelaide, Australia, 2004.

21. Labuschagne, C.; Brent, A.C.; Van Erck, R.P.G. Assessing the sustainability performances of industries. J. Clean. Prod. 2005, 13. [CrossRef]

22. Bramley, G.; Dempdey, N.; Power, S.; Brown, C.; Watkins, D. Social sustainability and urban form: Evidence from five British cities. Environ. Plan. A 2009, 41, 2125-2142. [CrossRef]

23. Dreyer, L.C.; Hauschild, M.Z.; Schierbeck, J. A framework for social life cycle impact assessment. Int. J. Life Cycle Assess. 2006, 11. [CrossRef]

24. Norris, G.A. Social impacts in product life cycles: Towards life cycle attribute assessment. Int. J. Life Cycle Assess. 2006, 11, 97-104. [CrossRef]

25. Hunkeler, D. Societal LCA methodology and case study. Int. J. Life Cycle Assess. 2006, 11, 371-382. [CrossRef]

26. Schmidt, I.; Meurer, M.; Saling, P.; Kicherer, A.; Reuter, W.; Gensch, C.O. SEEbalance ${ }^{\circledR}$ : Managing sustainability of products and processes with the socio-eco-efficiency analysis by BASF. Green. Manag. Int. 2004, 45, 79-94.

27. Yawar, S.A.; Seuring, S. Management of Social Issues in Supply Chains: A Literature Review Exploring Social Issues, Actions and Performance Outcomes. J. Bus. Ethics 2017. [CrossRef]

28. Creţan, R.; O'Brien, T. Corruption and conflagration: (In)justice and protest in Bucharest after the Colectiv fire. Urban Geogr. 2020. [CrossRef]

29. Badri Ahmadi, H.; Kusi-Sarpong, S.; Rezaei, J. Assessing the social sustainability of supply chains using Best Worst Method. Resour. Conserv. Recycl. 2017. [CrossRef]

30. Rajesh, R. Exploring the sustainability performances of firms using environmental, social, and governance scores. J. Clean. Prod. 2020. [CrossRef]

31. López-Martínez, G.; Espeso-Molinero, P. Pesca artesanal y patrimonio cultural en la Región de Murcia El pescador murciano como transmisor cultural. Rev. Murc. Antropol. 2019, 27. [CrossRef]

32. Creţan, R. Who owns the name? Fandom, social inequalities and the contested renaming of a football club in Timişoara, Romania. Urban Geogr. 2019. [CrossRef]

33. Ikram, M.; Zhou, P.; Shah, S.A.A.; Liu, G.Q. Do environmental management systems help improve corporate sustainable development? Evidence from manufacturing companies in Pakistan. J. Clean. Prod. 2019, 226. [CrossRef]

34. Svensson, G.; Ferro, C.; Høgevold, N.; Padin, C.; Carlos Sosa Varela, J.; Sarstedt, M. Framing the triple bottom line approach: Direct and mediation effects between economic, social and environmental elements. J. Clean. Prod. 2018, 197. [CrossRef]

35. Awan, U.; Khattak, A.; Kraslawski, A. Corporate Social Responsibility (CSR) Priorities in the Small and Medium Enterprises (SMEs) of the Industrial Sector of Sialkot, Pakistan. In Corporate Social Responsibility in the Manufacturing and Services Sectors; Springer: Berlin/Heidelberg, Germany, 2019.

36. Wang, H.; Tong, L.; Takeuchi, R.; George, G. Corporate social responsibility: An overview and new research directions. Acad. Manag. J. 2016, 59, 534-544. [CrossRef]

37. Shahzad, M.; Qu, Y.; Ur Rehman, S.; Zafar, A.U.; Ding, X.; Abbas, J. Impact of knowledge absorptive capacity on corporate sustainability with mediating role of CSR: Analysis from the Asian context. J. Environ. Plan. Manag. 2020, 63. [CrossRef]

38. Suganthi, L. Examining the relationship between corporate social responsibility, performance, employees' pro-environmental behavior at work with green practices as mediator. J. Clean. Prod. 2019, 232. [CrossRef]

39. Creţan, R. Mapping protests against dog culling in post-communist Romania. Area 2015. [CrossRef]

40. Anser, M.K.; Zhang, Z.; Kanwal, L. Moderating effect of innovation on corporate social responsibility and firm performance in realm of sustainable development. Corp. Soc. Responsib. Environ. Manag. 2018, 25. [CrossRef]

41. Bocquet, R.; Le Bas, C.; Mothe, C.; Poussing, N. CSR, Innovation, and Firm Performance in Sluggish Growth Contexts: A Firm-Level Empirical Analysis. J. Bus. Ethics 2017, 146. [CrossRef]

42. Martínez Veiga, U. Historia de la Antropología, Teorías, Praxis y Lugares de Estudio; Universidad Nacional de Educación a Distancia (UNED): Madrid, Spain, 2008.

43. Zhu, Q.; Zou, F.; Zhang, P. The role of innovation for performance improvement through corporate social responsibility practices among small and medium-sized suppliers in China. Corp. Soc. Responsib. Environ. Manag. 2019, 26. [CrossRef]

44. Chen, Y.S. The driver of green innovation and green image-Green core competence. J. Bus. Ethics 2008, 81. [CrossRef] 
45. Fernando, Y.; Chiappetta Jabbour, C.J.; Wah, W.X. Pursuing green growth in technology firms through the connections between environmental innovation and sustainable business performance: Does service capability matter? Resour. Conserv. Recycl. 2019, 141. [CrossRef]

46. Lin, H.; Zeng, S.X.; Ma, H.Y.; Qi, G.Y.; Tam, V.W.Y. Can political capital drive corporate green innovation? Lessons from China. J. Clean. Prod. 2014, 64. [CrossRef]

47. Weng, H.H.R.; Chen, J.S.; Chen, P.C. Effects of green innovation on environmental and corporate performance: A stakeholder perspective. Sustainability 2015, 7. [CrossRef]

48. Domenech, T.; Bleischwitz, R.; Doranova, A.; Panayotopoulos, D.; Roman, L. Mapping Industrial Symbiosis Development in Europe typologies of networks, characteristics, performance and contribution to the Circular Economy. Resour. Conserv. Recycl. 2019, 141. [CrossRef]

49. Mongeon, P.; Paul-Hus, A. The journal coverage of Web of Science and Scopus: A comparative analysis. Scientometrics 2016, 106. [CrossRef]

50. Martín Gómez, A.M.; Aguayo González, F.; Marcos Bárcena, M. Smart eco-industrial parks: A circular economy implementation based on industrial metabolism. Resour. Conserv. Recycl. 2018, 135. [CrossRef]

51. Tseng, M.L.; Islam, M.S.; Karia, N.; Fauzi, F.A.; Afrin, S. A literature review on green supply chain management: Trends and future challenges. Resour. Conserv. Recycl. 2019, 141, 145-162. [CrossRef]

52. Garcia-Muiña, F.E.; González-Sánchez, R.; Ferrari, A.M.; Settembre-Blundo, D. The paradigms of Industry 4.0 and circular economy as enabling drivers for the competitiveness of businesses and territories: The case of an Italian ceramic tiles manufacturing company. Soc. Sci. 2018, 7, 255. [CrossRef]

53. Meseguer-Sánchez, V.; Abad-Segura, E.; Belmonte-Ureña, L.J.; Molina-Moreno, V. Examining the research evolution on the socio-economic and environmental dimensions on university social responsibility. Int. J. Environ. Res. Public Health 2020, 17, 4729. [CrossRef] [PubMed]

54. Krüger, O. The role of ecotourism in conservation: Panacea or Pandora's box? Biodivers. Conserv. 2005. [CrossRef]

55. Cobbinah, P.B. Contextualising the meaning of ecotourism. Tour. Manag. Perspect. 2015. [CrossRef]

56. Weaver, D.B.; Lawton, L.J. Twenty years on: The state of contemporary ecotourism research. Tour. Manag. 2007. [CrossRef]

57. Núñez-Cacho, P.; Górecki, J.; Molina, V.; Corpas-Iglesias, F.A. How to measure and predict degree of circularity thinking in construction sector?-Modern way to build competitive advantage. In Proceedings of the 30th International Business Information Management Association Conference (IBIMA 2017)—Vision 2020: Sustainable Economic Development Innovation Management, and Global Growth, Madrid, Spain, 8-9 November 2017.

58. Al-Tuwaijri, S.A.; Christensen, T.E.; Hughes, K.E. The Relations Among Environmental Disclosure, Environmental Performance, and Economic Performance: A Simultaneous Equations Approach. SSRN Electron. J. 2005. [CrossRef]

59. Frankle, A.W.; Anderson, J.C. The Impact of the Disclosure of the Environmental Effects of Organizational Behavior on the Market: Comment. Financ. Manag. 1978, 7. [CrossRef]

60. Herbohn, K.; Walker, J.; Loo, H.Y.M. Corporate Social Responsibility: The Link Between Sustainability Disclosure and Sustainability Performance. Abacus 2014, 50. [CrossRef]

61. Orlitzky, M.; Schmidt, F.L.; Rynes, S.L. Corporate social and financial performance: A meta-analysis. Organ. Stud. 2003, 24. [CrossRef]

62. Porter, M.E.; Kramer, M.R. Creating Shared Value. Harv. Bus. Rev. 2011, 89, 62-77.

63. Lin, C.H.; Yang, H.L.; Liou, D.Y. The impact of corporate social responsibility on financial performance: Evidence from business in Taiwan. Technol. Soc. 2009, 31. [CrossRef]

64. Ruf, B.M.; Muralidhar, K.; Brown, R.M.; Janney, J.J.; Paul, K. An empirical investigation of the relationship between change in corporate social performance and financial performance: A stakeholder theory perspective. J. Bus. Ethics 2001, 32. [CrossRef]

65. Waddock, S.A.; Graves, S.B. The corporate social performance-financial performance link. Strateg. Manag. J. 1997, 18. [CrossRef]

66. Wagner, M. The role of corporate sustainability performance for economic performance: A firm-level analysis of moderation effects. Ecol. Econ. 2010, 69. [CrossRef]

67. Mahoney, L.; Roberts, R.W. Corporate social performance, financial performance and institutional ownership in Canadian firms. Account. Forum 2007, 31. [CrossRef]

68. Parast, M.M.; Adams, S.G. Corporate social responsibility, benchmarking, and organizational performance in the petroleum industry: A quality management perspective. Int. J. Prod. Econ. 2012, 139. [CrossRef]

69. Saeidi, S.P.; Sofian, S.; Saeidi, P.; Saeidi, S.P.; Saaeidi, S.A. How does corporate social responsibility contribute to firm financial performance? The mediating role of competitive advantage, reputation, and customer satisfaction. J. Bus. Res. 2015, 68. [CrossRef]

70. Benavides-Velasco, C.A.; Quintana-García, C.; Marchante-Lara, M. Total quality management, corporate social responsibility and performance in the hotel industry. Int. J. Hosp. Manag. 2014, 41. [CrossRef]

71. Pätäri, S.; Arminen, H.; Tuppura, A.; Jantunen, A. Competitive and responsible? The relationship between corporate social and financial performance in the energy sector. Renew. Sustain. Energy Rev. 2014, 37, 142-154. [CrossRef]

72. Boesso, G.; Kumar, K. Drivers of corporate voluntary disclosure: A framework and empirical evidence from Italy and the United States. Account. Audit. Account. J. 2007, 20. [CrossRef]

73. Campbell, J.L. Why would corporations behave in socially responsible ways? An institutional theory of corporate social responsibility. Acad. Manag. Rev. 2007, 32, 946-967. [CrossRef] 
74. Cormier, D.; Magnan, M.; Van Velthoven, B. Environmental disclosure quality in large German companies: Economic incentives, public pressures or institutional conditions? Eur. Account. Rev. 2005, 14. [CrossRef]

75. Gamble, G.O.; Hsu, K.; Jackson, C.; Tollerson, C.D. Environmental disclosures in annual reports: An international perspective. Int. J. Account. 1996, 31. [CrossRef]

76. Archel, P.; Husillos, J.; Spence, C. The institutionalisation of unaccountability: Loading the dice of Corporate Social Responsibility discourse. Account. Organ. Soc. 2011, 36. [CrossRef]

77. Banerjee, S.B.; Bonnefous, A.M. Stakeholder management and sustainability strategies in the French nuclear industry. Bus. Strateg. Environ. 2011, 20. [CrossRef]

78. Brammer, S.; Millington, A. Stakeholder Pressure, Organizational Size, and the Allocation of Departmental Responsibility for the Management of Corporate Charitable Giving. Bus. Soc. 2004, 43. [CrossRef]

79. Brammer, S.; Millington, A. The evolution of corporate charitable contributions in the UK between 1989 and 1999 : Industry structure and stakeholder influences. Bus. Ethics A Eur. Rev. 2003, 12. [CrossRef]

80. Vesalon, L.; Creţan, R. Development-induced displacement in Romania: The case of Roşia Montană mining project. J. Urban Reg. Anal. 2012. [CrossRef]

81. Cobo, M.J.; López-Herrera, A.G.; Herrera-Viedma, E.; Herrera, F. An approach for detecting, quantifying, and visualizing the evolution of a research field: A practical application to the Fuzzy Sets Theory field. J. Informetr. 2011, 5. [CrossRef]

82. Lievrouw, L.A. The Invisible College Reconsidered: Bibliometrics and the Development of Scientific Communication Theory. Commun. Res. 1989, 16. [CrossRef]

83. Harzing, A.W.; Alakangas, S. Google Scholar, Scopus and the Web of Science: A longitudinal and cross-disciplinary comparison. Scientometrics 2016, 106. [CrossRef]

84. Zhang, L.; Eichmann-Kalwara, N. Mapping the Scholarly Literature Found in Scopus on "Research Data Management": A Bibliometric and Data Visualization Approach. J. Librariansh. Sch. Commun. 2019, 7. [CrossRef]

85. European Commission. Green Paper: Promoting a European Framework for Corporate Social Responsibility; European Commission: Brussels, Belgium, 2001.

86. Belmonte-Urenã, L.J.; Garrido-Cardenas, J.A.; Camacho-Ferre, F. Analysis of world research on grafting in horticultural plants. HortScience 2020, 55, 112-120. [CrossRef]

87. Meseguer-Sánchez, V.; López-Martínez, G.; Molina-Moreno, V.; Belmonte-Ureña, L.J. The Role of Women in a Family Economy. A Bibliometric Analysis in Contexts of Poverty. Sustainability 2020, 12, 10328. [CrossRef]

88. Sedighi, M. Application of word co-occurrence analysis method in mapping of the scientific fields (case study: The field of Informetrics). Libr. Rev. 2016, 65. [CrossRef]

89. Van Eck, N.J.; Waltman, L. Bibliometric mapping of the computational intelligence field. Int. J. Uncertain. Fuzziness Knowl. Based Syst. 2007, 15, 625-645. [CrossRef]

90. Reyes-Menendez, A.; Saura, J.R.; Thomas, S.B. Exploring key indicators of social identity in the \#MeToo era: Using discourse analysis in UGC. Int. J. Inf. Manag. 2020. [CrossRef] 